\title{
Incorporating International Financial Reporting Standards (IFRS) into Accounting Curricula: Perceptions of Undergraduate Accounting Students in Saudi Universities
}

\author{
Ibrahim El-Sayed Ebaid \\ Department of Accounting, Faculty of Commerce, \\ Tanta university, Egypt and Umm Al-Qura University, Saudi Arabia,
}

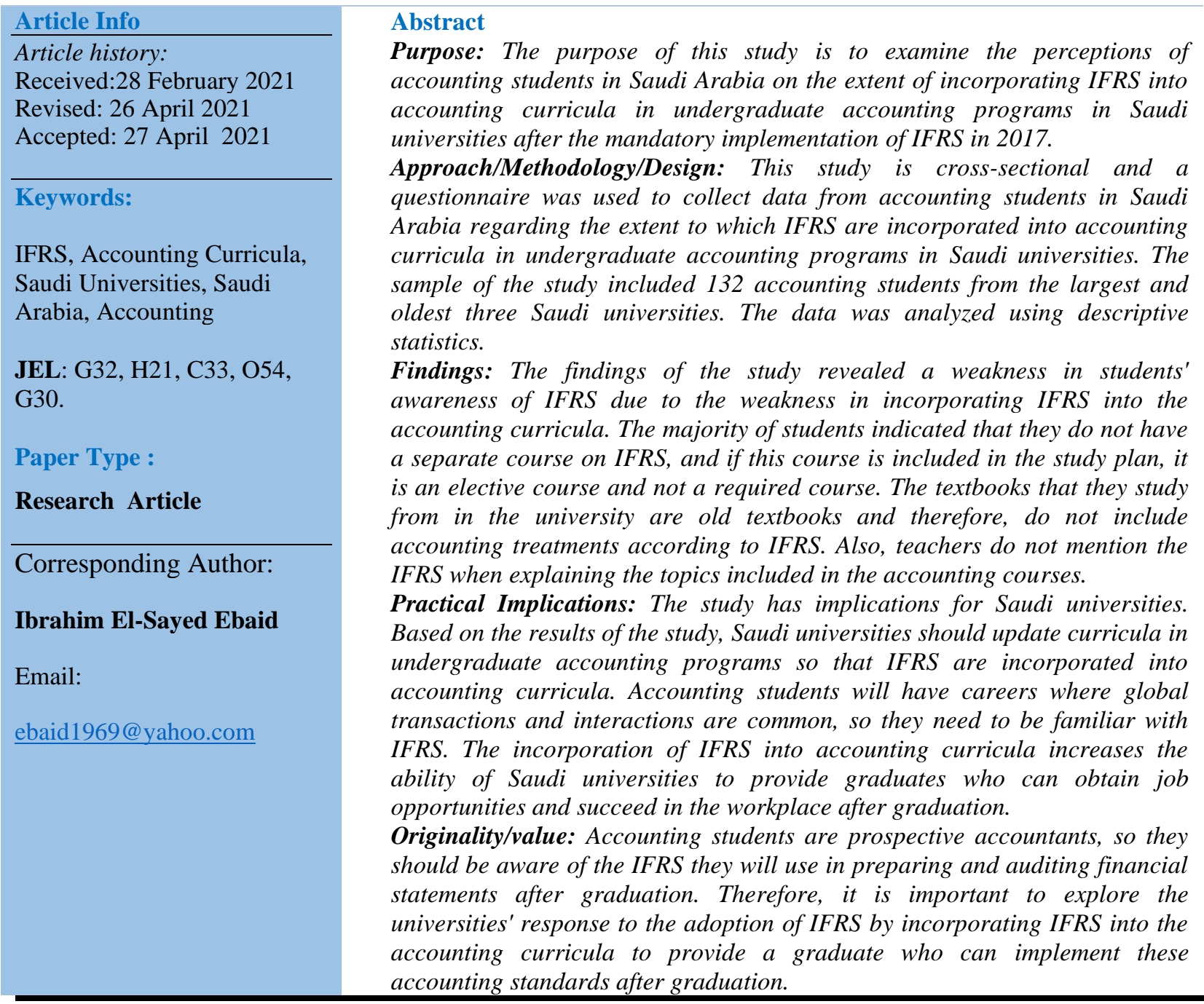

\section{Introduction}

Financial reporting plays a major role in economic development at the national and international levels through its impact on ensuring strong investor confidence, which is vital for the optimal performance of financial markets and, thus, for economic development. Before the coming of IFRS, different accounting standards sets were followed worldwide to tap varied national economic and social forces. Much of the diversity has resulted from deeply entrenched 
differences in legal systems, income tax systems, historical, political and economic ties, size and complexity of business enterprises, development of the financial market, sources of investment and financing, the level of community education, predominant culture and language and the overall economic development. Every country developed different accounting standards set such as the US's Generally Accepted Accounting Principles (USGAAP), UKGAAP, etc. and carried into practice it in the curricula of their business schools. These different accounting standards sets provide different accounting choices, applications of which, therefore, result in different financial reporting quality.

The debate on international harmonization of accounting standards has formally commenced in 1973 with the establishment of the International Accounting Standards Committee (IASC) which came into existence on June 29, 1973. In 1997 the committee began developing standards by forming a special committee to deal with the issue of financial instruments and financial derivatives. In 1998, four European countries, namely England, Germany, France and Belgium, issued national laws that allow large companies to apply international accounting standards within each country. As a result of this, the finance ministers of the Group of Seven industrialized countries issued a statement calling for the adoption and support of international accounting standards. In 2000, the Basel Committee, which is concerned with banking affairs, declared its support and acceptance of international accounting standards (IASs), and in the same year, 30 standards were accepted by the International Organization of Exchanges (IOSCO), whereby companies were allowed to use these standards outside the borders of their original home. In 2002, the European Union (EU) Parliament approved a regulation (Regulation 1606/2002) that mandates all companies registered in the EU stock markets to adopt International Financial Reporting Standards (IFRS) in preparing consolidated and stand-alone financial statements commencing after 1 January 2005. Since then, IFRS has begun to spread in all countries of the world. For example, the International Accounting Standards Board stated on its website that the number of countries adopting International Financial Reporting Standards by the end of 2017 had exceeded 150 countries. The globalization of financial markets at the present time has increased the need for a unified set of accounting standards for measurement and reporting that are applicable on an international scale, as accounting information is one of the main sources for dealing and making decisions in these markets (Surianti \&Yadiati, 2017). Okpala (2012) described IFRS as a global Generally Accepted Accounting Principles (GAAP), setting principles-based and globally accepted standards published by the IASB to facilitate preparation and presentation of high quality, transparent and comparable financial statements.

However, effective implementation of IFRS demands considerable and adequate technical capacity among preparers, users, auditors, regulatory bodies, investors and even the public. Technical capacity, therefore, is a basic requirement for effective implementation of IFRS. Thus, one major challenge encountered in the implementation process is the shortage of skilled accountants and auditors who are technically competent in implementing IFRS. Karr (2008) points out that financial statement preparers, auditors, investors, regulators, stock exchanges, financial analysts are not the only groups that would need training in IFRS. Accounting students and accounting educators also need this training. Poor IFRS education is one of the major

Copyright (C) 2021, Journal of Advanced Research in Economics and Administrative Sciences (JAREAS), Under a Creative Commons Attribution 4.0 International License 
bottlenecks for successful IFRS implementation identified by IASB (2019). The adoption of IFRS for accounting education is considered important due to the role played by accounting educators in providing graduates for the business world globally. Accounting students will have careers where global transactions and interactions are common, so they will need to be familiar with IFRS and sensitive to the rapidly changing accounting environment. Universities should prepare their students for this tremendous change, which will affect not only accounting, but also core financial aspects of all public companies. Zeghal and Mhedhbi (2006) state that the level of education has a positive effect on the process of adopting IFRS. Thomas (2009) argues that educating the future generation of professionals and corporate managers in IFRS principles is critical because it will enable them to develop consistent financial statements and make informed decisions in an increasingly global marketplace. Owolabi et al. (2016) affirmed that effective IFRS could be achieved through review of accounting curricula, especially in the tertiary education system, to incorporate IFRS. Chartered Accountants of Australia and New Zealand (2017) opined that IFRS education seek to make graduates up-to-date on IFRS, understand the fundamental requirements of IFRS, speak the global language of accounting, stay relevant and add value to the accounting profession. However, prior studies have provided evidence that the incorporation of IFRS into accounting curricula in universities, especially in developing countries, is still not at the appropriate level (e.g., Bajaj et al., 2019; Okorie et al., 2018; NL, 2018; Ediraras et al., 2017; Chimtengo et al., 2017; AlMotairy and AlTorky, 2012). This weakness in incorporating IFRS into accounting curricula in these countries could negatively affect the effectiveness of implementing IFRS. Currently accounting students as prospective accountants and auditors are required to be able to understand IFRS, so the incorporation of IFRS in the accounting curricula is needed to produce graduates that have capable of preparing and auditing the financial statements after graduation.

In 2012, the Saudi Organization for Certified Public Accountants (SOCPA) has approved an IFRS convergence plan, called the "SOCPA Project for Transition to International Accounting \& Auditing Standards". In 2016, SOCPA adopted all of the IFRS Standards (including interpretations) based on the IFRS 2017 Red Book, without amending any requirements in those standards. Under this convergence plan, all listed companies are required to adopt IFRS for financial periods beginning on or after January 1, 2017. Accordingly, accounting students in Saudi universities who are prospective accountants must be aware of details about IFRS, must understand the information presented in companies' financial statements, be aware of changes in Saudi financial accounting and reporting rules, and implications of such changes for business entities and financial statement users. Unfortunately, the studies conducted in Saudi Arabia after the announcement of the transition plan to IFRS in 2012 provided evidence that universities did not make sufficient effort to prepare students for this change by incorporating IFRS into accounting curricula. AlMotairy and AlTorky (2012) found that the majority (65 per cent) of surveyed universities in Saudi Arabia did not presently incorporate IFRS in their accounting curricula. Alzeban (2016) documented some of the challenges faced by accounting educators in Saudi universities in their attempts to incorporate IFRS materials in their teaching which include instructor's attitude, teaching load, teaching experience and teaching materials. Now, after more

Copyright (C) 2021, Journal of Advanced Research in Economics and Administrative Sciences (JAREAS), Under a Creative Commons Attribution 4.0 International License 
than four years of the mandatory implementation of IFRS in Saudi Arabia, is there still a weakness in integrating IFRS into accounting curricula in undergraduate accounting programs in Saudi universities? This is the main question of this study. Therefore, this study aims to explore the extent to which IFRS have been incorporated in accounting curricula in undergraduate accounting programs in Saudi universities at present. To achieve this goal, the study was organized as follows: Section 2 examines extant literature on incorporating IFRS into accounting curricula. Section 3 explains the research method used in this study and Section 4 reports the result of the study, while Section 5 is conclusion and limitations.

\section{Literature Review}

\section{Adoption of IFRS in Saudi Arabia}

Since Saudi Arabia joined the Group of Twenty Finance Ministers and Central Bank Governors (G20) in 2009, the adoption of IFRS has been viewed as an important milestone in the country's future economic development and has been working towards this end ever since. In April 2016, Saudi Arabia announced an ambitious economic program called "Saudi Arabia's Vision for 2030" which expresses Saudi Arabia's long-term goals and expectations and it is built upon the country's unique strengths and capabilities. This vision guides the country's aspirations towards a new phase of economic development aims to diversify sources of income instead of relying solely on oil, creating more job opportunities via encouraging investment, both domestic and foreign, encouraging the major Saudi corporations to expand across borders and take their rightful place in global markets and providing better opportunities for partnerships with the private sector. In an era of globalization of businesses and markets, financial information prepared and audited according to national accounting and auditing standards no longer satisfies the needs of users whose decisions are more international in scope. Saudi Arabia has recognized the need to participate in the opportunities offered by globalization. Consequently, to attract direct foreign investment to the country, The Saudi Organization of Certified Public Accountants (SOCPA), in a parallel step with the preparation of Saudi Arabia's Vision for 2030, has approved an IFRS convergence plan, called the "SOCPA Project for Transition to International Accounting \& Auditing Standards" in 2012. In 2016, SOCPA adopted all of the IFRS Standards (including Interpretations) based on the IFRS 2017 Red Book, without amending any requirements in those standards. Under this convergence plan, all listed companies are required to adopt IFRS for financial periods beginning on or after January 1, 2017 with some modifications resulting in additional disclosures and ensuring compliance with Shariah as a single set of high quality, understandable, enforceable and globally accepted standards for financial reporting. Also, the Saudi Arabian Monetary Authority (currently called Saudi Central Bank) requires all banks and insurance companies to use IFRS Standards. SOCPA argues that the transition to IFRS promises transparent, comparable and consistent financial information to guide investors in making optimal investment decisions. Some of the key benefits that the companies will enjoy from IFRS adoption include increased foreign direct investment (FDI), enhanced quality reporting, transparency and comparability, and more transparency to perform

Copyright (C) 2021, Journal of Advanced Research in Economics and Administrative Sciences (JAREAS), Under a Creative Commons Attribution 4.0 International License 
risk assessments on financial statements and other ratios. In a parallel step, SOCPA has endorsed an integrated set of auditing standards- based basically on international auditing standards. All accounting firms in Saudi Arabia are required to adopt this integrated set of auditing standards for financial periods beginning on or after January 1, 2017. Because the business sector is important in achieving the objectives of Saudi Arabia's economic vision 2030, and this includes not only large (listed) entities but the much more numerous small and medium-sized entities (SMEs), SOCPA adopted IFRS for SMEs as of January 2018. All SMEs in Saudi Arabia are required to adopt IFRS for SMEs for financial periods beginning on or after January 1, 2018. SOCPA has adopted the 2015 version of the IFRS for small and medium-sized entities (SMEs) Standard.

\section{Status of the Incorporation of IFRS into Accounting Curricula}

The financial statements of U.S. publicly held companies have historically been prepared based on the well-established reporting standards known as Generally Accepted Accounting Principles (GAAP). Over the last two decades, the U.S. Securities and Exchange Commission (SEC) has been considering a move to the International Financial Reporting Standards (IFRS) for companies under its jurisdiction. Accordingly, several studies have dealt with incorporation of IFRS into accounting curricula, either in terms of the extent to which American universities incorporate standards into accounting curricula or suggest strategies for this incorporation. For example, Kinkela et al. (2010) examined strategies for incorporating IFRS into the introductory levels of the accounting curricula. They advocated that IFRS education should be incorporated into each introductory level course in accounting. They also demonstrated that a basic knowledge of IFRS is essential to the business vocabulary for both accounting and nonaccounting majors. Bandyopadhyay and McGee (2012) prepared a report on the convergence of IFRS and USGAAP in terms of its impact on curricula in higher education. They stated that the AICPA was testing candidates on IFRS in the CPA exam since 2011. For this reason, 14 of 36 institutions in the US already accredited their curricula in IFRS commonly with the intermediate accounting courses. Clay (2013) applied semi-structured interviews with accounting professor and practitioners and found that lower- level courses such as Financial Accounting I-II were not affected by IFRS, conversely, intermediate- level accounting courses were the most affected. Gallagher (2013) examined the coverage of IFRS in private colleges and universities in Pennsylvania. He found that a small percentage of the universities have a stand-alone course in international accounting and the coverage of the IFRS is not consistent from college to college. Kang et al. (2016) investigated whether business schools located in the Midwestern United States are ready for the transition to IFRS and found that most of the schools surveyed do not currently offer international accounting course, either as a required or an elective.

Outside the United States, many studies have been conducted to examine the extent to which IFRS are incorporated into the accounting curricula. AlMotairy and AlTorky (2012) conducted a survey of participating accounting faculty members in Saudi Arabia universities. They found that $100 \%$ of the faculty members in Saudi universities agree to the necessity of teaching the IFRS within the universities. However, $75 \%$ of these faculty members are not currently teaching

Copyright (C) 2021, Journal of Advanced Research in Economics and Administrative Sciences (JAREAS), Under a Creative Commons Attribution 4.0 International License 
IFRS to their students and they are not expanding their knowledge on IFRS. $36 \%$ of the faculty members in Saudi universities who participated in the survey have basic to medium knowledge of IFRS. Herbert et al. (2013) examined the extent of IFRS familiarity by academics and practitioners in Nigeria and the state of readiness to embrace IFRS by academics and practitioners. They showed significant differences between accounting students, lecturers and practitioners with respect to their degree of familiarity with IFRS. Also, Lanre et al. (2014) studied the integration of IFRS into accounting curricula in Nigeria and revealed that students are aware of issues that relates to IFRS meaning and they have sufficient knowledge of the standards. Jackling et al. (2013) investigated the transition process to IFRS in Australia in terms of teaching approaches for accounting education in universities. They showed that the transition process required minimal changes because of the similarity between the Australian GAAP and IFRS. Accordingly, academics were reluctant to update existing textbooks and teaching approaches concerning IFRS education. Yllmaz et al. (2014) evaluated the awareness of the senior students in business administration about the IFRS in six universities in Turkey and found that students are not aware of the concept of the IFRS adequately. They also found that academics teach IFRS in their graduate- level accounting courses but not yet in undergraduatelevel courses. Yilmaz and Yazarkan (2017) made a comparison between curricula of 50 business schools ranked by QS and 50 business schools in Turkey in terms of offered International Accounting Standards (IAS) or International Financial Reporting Standards (IFRS) courses. They found that while IAS/IFRS courses are offered commonly in Turkey, only a few related courses are offered in the world. Ediraras et al. (2017) analyzed the differences in perceptions of IFRS integration into accounting curriculum between female students with male students, and students who are under or equal to 20 years with a student over the age of 20 years in Indonesia. Their results stated that there was a difference between the perception of female students with male students about the integration of IFRS into accounting curricula, and there is no difference in perception between students aged below or equal to 20 years with a student over the age of 20 years. Chimtengo et al. (2017) examined the extent to which IFRS have been incorporated in the curricula of universities and colleges offering accounting degree programs in Malawi. They found that IFRS have been incorporated into the accounting curricula of only five universities and colleges. Their results also indicated that the coverage of the standards was at different ranges. NL (2018) made some comments on the development opportunities of young lecturers in Indonesia when teaching accounting in accordance with International Financial Reporting Standards (IFRS) such as: help universities to gain competitive advantage in the context of integration, opportunity for young instructors to deliver creative teaching methods and trained students in the university will have better access to accounting after graduation. Bajaj et al. (2019) examined the extent to which IFRS have been incorporated in the curriculum of universities in India and found that most of the students were not aware of the IFRS and there were no differences in knowledge about IFRS for different gender among students. They also found that most of the students were fascinated with taking IFRS in the framework of their course.

Copyright @ $\odot$ 2021, Journal of Advanced Research in Economics and Administrative Sciences (JAREAS), Under a Creative Commons Attribution 4.0 International License 


\section{Factors Affecting Incorporating IFRS into Accounting Curricula}

Prior studies examined the factors that hinder the process of integrating IFRS into accounting curricula. For example, Yallapragada et al. (2011) showed the problems that most educators have identified with incorporating IFRS into accounting curricula in the USA. The two main problems identified were lack of faculty training and lack of adequate textbook materials. Jackling et al. (2012) addressed challenges that accounting educators face in their teaching International Financial Reporting Standards (IFRS) in Australia, United States and Romania and showed that teaching resources, educational research and continuing professional development are necessary for educators to enrich the learning experience of students. Coetze and Schmulian (2013) highlighted two significant problems related to incorporating IFRS into accounting education in South Africa. First, the challenge is shifting from rule-based pedagogy to framework-based teaching of financial reporting. Second, the references for the financial reporting standards were not available in Afrikaans language, and as a result there were complexities associated with the translation from English to Afrikaans.

Alzeban (2016) examined the challenges faced by accounting educators in their attempts to incorporate IFRS materials in their teaching in Saudi universities His results indicated that the instructor's attitude and availability of IFRS materials exert the most influence upon the time spent by teachers on the IFRS. He further found that departmental support, familiarity with IFRS, training and teaching experience in IFRS are positively associated with the time spent on teaching the IFRS. Ediraras et al. (2017) showed that the problems that facing the incorporating of IFRS into accounting curricula in Indonesia were limited lecturing materials (textbooks) owned by educational institutions, lecturing time, and abilities / skills of lecturers. Aldredge (2018) investigated potential relationships among five independent variables (educator rank, institution size, IFRS familiarity, IFRS uncertainty, timing of U.S. IFRS adoption) and IFRS course coverage in the USA and found that only one factor, IFRS familiarity, was significantly related to IFRS course coverage. Lakew and Musa (2019) examined problems in teaching IFRS in Ethiopian universities. They found that the level of preparedness to incorporate IFRS is low in the majority of the universities. Their results showed that lack of textbooks in line with IFRS, the problem of integrating IFRS in to the curricula and lack of practical experiences of teachers are the top three bottlenecks that hinder teaching IFRS. Septriana and Fuad (2020) examined the effect of learning readiness, learning experiences, learning behaviour and teaching quality of lecturers on IFRS understanding in accounting students in Indonesia. Their results showed that only the readiness of learning affects the understanding of IFRS in accounting students, while the learning experience, learning behaviour and teaching quality of lecturers did not affect the understanding of IFRS in accounting students.

\section{Methodology and Procedures}

\section{Sample}

Currently accounting students as prospective accountants and auditors are required to be able to understand IFRS, so the incorporation of IFRS in accounting curricula is needed to produce

Copyright (C) 2021, Journal of Advanced Research in Economics and Administrative Sciences (JAREAS), Under a Creative Commons Attribution 4.0 International License 
graduates who are able to prepare and audit financial reports based on IFRS. This study aims to explore the extent to which IFRS are incorporated into accounting curricula in Saudi universities. Participants of this study are 7th-level and 8th-level students in accounting departments from three Saudi universities: Umm Al-Qura University, King Abdulaziz University and King Saud University. The reason for choosing these three universities is that these universities are the largest and oldest universities in Saudi Arabia. The study focused on 7th-level and 8th-level accounting students because they have already studied most of the accounting courses included in their study plan, consequently, they will have a better ability to assess the extent to which IFRS are incorporated into accounting curricula. The questionnaire was sent by email to all students enrolled in 7th-level and 8th-level in accounting departments from the three Saudi universities. A total of 193 questionnaires were sent to the participating groups. Out of this number, 146 were returned representing 75.6 percent response rate. In total, 14 of the questionnaires received were however excluded from the final analysis because respondents did not fully answer the questions set the remaining sample size of 132 students. Demographic profiles of the respondents are shown in Table (I). As shown in Table (1), all respondents are male, as mixing between males and females is prohibited in Saudi Arabia universities, and then there is difficulty in communicating with females. The majority of the respondents (84.8 percent) are between 21 and 25 years old. 117 respondents representing 88.6 $\%$ are in 7 th-level, as the study was conducted at the end of the first semester. In the first semester, registration is usually opened for students of the first, third, fifth and seventh levels, in addition to some courses of the eighth level for graduate students only.

Table I: Demographic Profiles of the Respondents

\begin{tabular}{lll}
\hline $\begin{array}{l}\text { Category } \\
\text { Gender }\end{array}$ & Scale & $\mathbf{N = 1 3 2 ( 1 0 0 \% )}$ \\
& Male & $132(100 \%)$ \\
& & \\
Age & Under 21 & $9(6.8 \%)$ \\
& $21-25$ & $112(84.8 \%)$ \\
& $26-30$ & $11(8.4 \%)$
\end{tabular}

Semester

7th-semester

$117(88.6 \%)$

8th-semester

$15(11.4 \%)$

Umm Al-Qura

University King Abdulaziz

$52(39.4 \%)$

$46(34.8 \%)$

King Saud

$34(25.8 \%)$

Source: Author

\section{Instrument}

This study is a cross-sectional survey that aims to collect field data on the perceptions of accounting students in Saudi Arabia universities towards the incorporation of IFRS into

Copyright (C) 2021, Journal of Advanced Research in Economics and Administrative Sciences (JAREAS), Under a 
accounting curricula. The questionnaire includes two main sections. The first section aims to collect demographic data on the participants. The second section aims to examine students' perceptions of the extent to which IFRS are incorporated into accountant curricula. This section contains 16 questions divided into three groups. The first group (includes four questions) aims to assess students' awareness of some general information about IFRS, the second group (includes four questions) aims to assess students' awareness of detailed information about the adoption of IFRS in Saudi Arabia, while the third group (includes eight questions) aims to identify students' perceptions of incorporating IFRS into accounting curricula. Most of these questions were obtained from previous studies that examined the incorporation of IFRS into accounting curricula in other countries (e.g., Bajaj et al., 2019; Okorie et al., 2018; NL, 2018; Ediraras et al., 2017; Chimtengo et al., 2017). The questionnaires were administered and collected during November and December 2020 and they were developed in the Arabic language.

\section{Results and Discussion}

The study conducts a descriptive analysis of the data collected through the questionnaires received from the respondents in the study to assess students' awareness of the IFRS and their perceptions of the extent to which the IFRS are incorporated into the accounting curricula. Table (2) shows the extent to which students have awareness of some general information about IFRS. As shown in Table (2), the majority of students (74.2\% of respondents) had heard of the term IFRS before. This may be attributed to the Saudi Organization for Certified Public Accountants (SOCPA) has organized many visits to accounting departments in Saudi universities in recent years to increase students' awareness of the accounting profession in Saudi Arabia. However, the majority of students are not aware of who issued IFRS (90.2\% of respondents), the history of harmonizing accounting standards at the international level (93.9\% of respondents). Also, the majority of students (94.7\% of respondents) are not aware of the difference between IFRS that are implemented by listed companies and IFRS for SMEs that are implemented by small and medium-sized entities that are not listed in the capital market. These results indicate a weakness in students' awareness of general information about IFRS, which indirectly indicates a weakness in incorporating IFRS into accounting curricula, given that accounting curricula are the main source for students to obtain information on accounting standards.

Table 2: Students' Awareness of General Information about IFRS

\begin{tabular}{|c|c|c|}
\hline \multirow{2}{*}{ Question } & \multicolumn{2}{|c|}{ Answer } \\
\hline & Yes & No \\
\hline 1- Have you ever heard of the term IFRS? & $98(74.2 \%)$ & $34(25.8 \%)$ \\
\hline 2- Do you know who is issuing IFRS? & $13(9.8 \%)$ & $119(90.2)$ \\
\hline $\begin{array}{l}\text { 3- Do you have information on the history of } \\
\text { harmonization of accounting standards at the } \\
\text { international level? }\end{array}$ & $8(6.1 \%)$ & $124(93.9 \%)$ \\
\hline $\begin{array}{l}\text { 4- Do you know the difference between IFRS and } \\
\text { IFRS for SMEs? }\end{array}$ & $7(5.3 \%)$ & $125(94.7 \%)$ \\
\hline
\end{tabular}

Source: Author

Copyright (C) 2021, Journal of Advanced Research in Economics and Administrative Sciences (JAREAS), Under a Creative Commons Attribution 4.0 International License 
Table (3) shows the extent to which students have awareness of some detailed information about IFRS. As shown in Table (3), the majority of students (74.2\% of the respondents) are aware of the board that has the right to mandate companies to implement IFRS in Saudi Arabia, which is the Saudi Organization for Certified Public Accountants (SOCPA). This may also be attributed to the SOCPA has organized visits to accounting departments in Saudi universities in recent years to increase students' awareness of the accounting profession in Saudi Arabia. However, Table (3) indicates a lack of students' knowledge of some detailed information about the IFRS. The majority of students (68.2\% of the respondents) have no awareness of the date of implementation of IFRS in Saudi Arabia. All students (100\% of the respondents) are not aware of the number of IFRS currently implemented in Saudi Arabia. Also, the majority of students (91.7\% of the respondents) are not aware of the difference between the local Saudi standards that were implemented before 2017 and the IFRS that began to be implemented in Saudi Arabia at the beginning of January 2017. Once again, these results indicate a weakness in students' awareness of detailed as well as general information about IFRS, which indirectly indicates a weakness in incorporating IFRS into accounting curricula, given that accounting curricula is the main source for students to obtain information on accounting standards.

Table 3: Students' Awareness of Detailed Information about the Adoption of IFRS in Saudi Arabia

\begin{tabular}{|c|c|c|}
\hline \multirow[t]{2}{*}{ Question } & \multicolumn{2}{|c|}{ Answer } \\
\hline & Yes & No \\
\hline $\begin{array}{l}\text { 1- Do you know who is responsible for mandating } \\
\text { companies to implement IFRS in Saudi Arabia? }\end{array}$ & $98(74.2 \%)$ & $34(25.8 \%)$ \\
\hline $\begin{array}{l}\text { 2- Do you know the date of mandating companies } \\
\text { to implement IFRS in Saudi Arabia? }\end{array}$ & $42(31.8 \%)$ & $90(68.2 \%)$ \\
\hline $\begin{array}{l}\text { 3- Do you know the number of IFRS effective } \\
\text { presently in Saudi Arabia? }\end{array}$ & $0(0 \%)$ & $132(100 \%)$ \\
\hline $\begin{array}{l}\text { 4- Do you know what the difference between local } \\
\text { Saudi standards and IFRS is? }\end{array}$ & $11(8.3 \%)$ & $121(91.7 \%)$ \\
\hline
\end{tabular}

Source: Author

Table (4) presents students' perceptions of the extent to which IFRS are incorporated into accounting curricula. As shown in Table (4), the majority of students (93.2\% of the respondents) expressed an interest in studying IFRS. The majority of students (93.2\% of the respondents) realized the importance of incorporating IFRS into accounting curricula. This may be due to the students' belief that obtaining job opportunities after graduation and success in the workplace after employment is related to having sufficient knowledge and skills of IFRS that are currently implemented in companies in Saudi Arabia. However, the answers to the remainder questions included in Table (4) illustrate the apparent weakness of interest in IFRS in Saudi universities. $39.4 \%$ of respondents indicated that there is no IFRS course within their study plan, which means that these students will graduate from the university without any knowledge of the IFRS. Even $60.6 \%$ of respondents who indicated that they have a course on IFRS indicate that this course is an elective course and not a required one, which means that some of them may not study this course. This also refers that the students will graduate from the university without 
sufficient knowledge of IFRS. 93.9\% of the students indicated that IFRS term was not mentioned in the textbooks from which they study at the university. This is may be considered as evidence that IFRS are not incorporated into the accounting curricula. This is confirmed by looking at the answer to question 6 in Table (4), where the students indicated that the textbooks they study from are old textbooks dating back to before 2017, and therefore these textbooks do not contain the accounting treatments according to IFRS.

Table 4: Students' Perceptions of Incorporating IFRS into Accounting Curricula

\begin{tabular}{|c|c|c|}
\hline \multirow[t]{2}{*}{ Question } & \multicolumn{2}{|c|}{ Answer } \\
\hline & Yes & No \\
\hline 1- Are you interested in learning IFRS? & $123(93.2 \%)$ & $9(6.8 \%)$ \\
\hline 2- Should IFRS be incorporated in curricula? & $123(93.2 \%)$ & $9(6.8 \%)$ \\
\hline 3- Does your study plan include a course on IFRS? & $80(60.6 \%)$ & $52(39.4 \%)$ \\
\hline $\begin{array}{l}\text { 4- If your study plan includes a course on IFRS, is } \\
\text { this course required (not elective)? }\end{array}$ & $0(0 \%)$ & $80(100 \%)$ \\
\hline $\begin{array}{l}\text { 5- Is the term IFRS mentioned in the textbooks that } \\
\text { you study from at the university? }\end{array}$ & $8(6.1 \%)$ & $124(93.9 \%)$ \\
\hline $\begin{array}{l}\text { 6- Are the textbooks for the accounting courses } \\
\text { from which you taught at the university recent } \\
\text { (2017 and beyond)? }\end{array}$ & $15(11.4 \%)$ & $117(88.6 \%)$ \\
\hline $\begin{array}{l}\text { 7- Is the conceptual framework of the financial } \\
\text { reporting according to IFRS taught in the course } \\
\text { of principles of accounting? }\end{array}$ & $11(8.3 \%)$ & $121(91.7 \%)$ \\
\hline $\begin{array}{l}\text { 8- Do teachers mention IFRS when dealing with } \\
\text { accounting topics that are taught in accounting } \\
\text { courses such as intermediate accounting or } \\
\text { advanced accounting? }\end{array}$ & $27(20.5 \%)$ & $105(79.5 \%)$ \\
\hline
\end{tabular}

Source: Author

Since the textbooks that students study from are old textbooks, this may explains the students' answer to question 7 in Table (4), where the majority of students (91.7\% of the respondents) indicated that the conceptual framework of financial reporting approved by the International Accounting Standards Board (IASB) is not studied in the course on principles of accounting. This is another indication of the weak incorporation of IFRS into accounting curricula. Finally, by looking at the answer to question 8 in Table (4), the majority of students $(79.5 \%$ of the respondents) indicated that teachers do not mention the term IFRS when explaining the accounting topics included in accounting courses such as the intermediate accounting course and the advanced accounting course. These courses are the most appropriate courses to integrate IFRS in accounting curricula as indicated by previous studies (e.g., Kang et al., 2016; Clay, 2013; Bandyopadhyay and McGee, 2012; Kinkela et al., 2010). The failure to incorporate IFRS into these courses is another evidence of a deficiency in Saudi universities in incorporating IFRS into accounting curricula.

In general, the above results indicate a weakness in incorporating IFRS into accounting curricula in undergraduate accounting programs in Saudi universities. This weakness means that

Copyright (C) 2021, Journal of Advanced Research in Economics and Administrative Sciences (JAREAS), Under a 
accounting students in Saudi universities, who are prospective accountants, do not have sufficient knowledge and competencies related to IFRS due to the weakness in incorporating IFRS into accounting curricula. This weakness is not commensurate with the efforts of the Saudi Organization of Certified Public Accountants (SOCPA) to develop the accounting profession in Saudi Arabia. This weakness could negatively affect the effectiveness of implementing IFRS in Saudi companies, which began at the beginning of January 2017. Also, this weakness could represent a challenge to the plans of the Ministry of Labor in Saudi Arabia, which aims to localize the accounting profession and limit work in it to Saudi graduates. These results impose challenges on Saudi universities to develop and update accounting curricula to incorporate IFRS in accounting courses to provide the student with sufficient knowledge of IFRS, which facilitates his opportunity to obtain a job as an accountant after graduation and also guarantees success in the work place after employment.

\section{Conclusion and Suggestion}

The globalization of financial markets at present has increased the speed of adoption of IFRS as a unified set of accounting standards for measurement and reporting that are applicable on an international scale, as accounting information is one of the main sources for dealing and making decisions in these markets. Saudi Arabia began implementing IFRS at the beginning of January 2017. However, one major challenge encountered in the implementation process is the shortage of skilled accountants and auditors who are technically competent in implementing IFRS. Therefore, poor IFRS education is one of the major bottlenecks for successful IFRS implementation identified by IASB. Accounting students will have careers where global transactions and interactions are common, so they need to be familiar with IFRS and sensitive to the rapidly changing accounting environment. Universities should to prepare their students for this tremendous change, which will affect not only accounting, but also core financial aspects of all public companies. This study aimed to explore the extent to which Saudi universities keep pace with the developments taking place in the accounting environment in Saudi Arabia by exploring the extent to which IFRS are incorporated into accounting curricula in undergraduate accounting programs in Saudi Arabia. The study was based on a questionnaire distributed to a sample of accounting students in Saudi universities. The results of the study indicated that there is a weakness in incorporating IFRS into accounting curricula in Saudi universities. Most students do not have a course on IFRS in their study plan. Even universities that have a course on IFRS, this course is an elective course and not a required course. Also, accounting textbooks in Saudi universities are old do not include accounting treatments according to IFRS. These results have implications for Saudi universities in terms of the need to update accounting curricula to incorporate IFRS, so the student will graduate with sufficient knowledge and competences of how to prepare and audit financial statements according to IFRS. However, this study has some limitations. This study focused on students' perceptions of the extent to which IFRS are incorporated into accounting curricula. Additional studies can examine teachers' perceptions of incorporating IFRS into accounting curricula and examine the causes behind weaknesses in this incorporation. Further studies can also compare the perceptions of students and teachers of incorporating IFRS into accounting curricula and explore the differences

Copyright (C) 2021, Journal of Advanced Research in Economics and Administrative Sciences (JAREAS), Under a 
between them. Other studies can also examine the perceptions of employers on their satisfaction with the skills and competencies of accounting graduates in the workplace in light of the implementation of IFRS in Saudi companies. Other studies can also examine the perceptions of officials in Saudi universities to identify the obstacles that stand behind the updating of undergraduate accounting programs curricula in Saudi universities to incorporate IFRS.

\section{Conflict of Interest}

The author of the article declares no conflict of interest.

\section{Funding}

This research study was not funded by any institution. The author conducted the study on his own expenses.

\section{References}

Aldredge, M. (2018). The Determinants of IFRS Coverage in the Undergraduate Accounting Curricula. Global Economy and Finance Journal, 11(2), 31-45.

AlMotairy, O. \&AlTorky, K. (2012). A Survey of the accounting curriculum and IFRS in Saudi Universities: academic perspectives. Journal of Administrative and Economics Science, 5(2), 98-131.

Alzeban, A. (2016). Factors influencing adoption of the international financial reporting standards (IFRS) in accounting education. Journal of International Education in Business, 9(1), 2-16.

Bajaj, N. Singh, H. \&Shirur, S. (2019). Adoption of International Financial Reporting Standards (IFRS) in Accounting Curriculum in India. International Journal of Innovative Technology and Exploring Engineering, 8(7), 208-2018.

Bandyopadhyay, J. \& McGee, P. (2012). A progress report: IFRS-U.S. GAAP convergence and its curriculum impact. Advances in Competitiveness Research, 20 (1/2), 78-89.

Chartered Accountants Australia and New Zealand (2017). Learning opportunities. IFRS Training Courses. Teredaccountantsanz.com. Retrieved 16th August, 2018.

Chimtengo, S., Hanif, R., Banda, F. \& Mkandawire, K. (2017). Analysis of International Financial Reporting Standards Content of Accounting Degree Curricula in Malawi. International Business and Management, 14(1), 25-32.

Clay, M. (2013). Incorporating International Financial Reporting Standards: IFRS in the accounting curriculum. Proceedings of the Northeast Business \& Economics Association, 35-39.

Coetze, S. \&Schmulian, A. (2013). The Effect of IFRS Adoption on Financial Reporting Pedagogy in South Africa. Issues in Accounting Education, 28(2), 243-251.

Ediraras, D., Putra, A. \&Purtiningrum, S. (2017). IFRS integration into accounting curriculum: Undergraduate accounting students' perceptions in Jakarta. Global Journal of Sociology, $7(1), 2-8$.

Copyright (C) 2021, Journal of Advanced Research in Economics and Administrative Sciences (JAREAS), Under a Creative Commons Attribution 4.0 International License 
Gallagher, M. (2013). The Incorporation of International Accounting Concepts in the Curriculum at Private Universities in the State of Pennsylvania. International Journal of Business Administration, 4(4), 9-15.

Herbert, W., Tsegba, I., Ohanele, A. \&Anyahara, I. (2013). Adoption of International Financial Reporting Standards (IFRS): Insights from Nigerian Academics and Practitioners. Research Journal of Finance and Accounting, 4(6), 121-135.

IASB (2019) International Financial Reporting Standard (IFRS) accessed from https://www.ifrs.org/groups/international-accounting-standards-board/

Karr, S. (2008). Climbing the Learning Curve from GAAP to IFRS. Financial Executive, (1)5, 46-49.

Jackling, B., Howieson, B. \&Natoli, R. (2012). Some Implications of IFRS Adoption for Accounting Education. Australian Accounting Review, 22(4), 331-340.

Jackling, B., de Lange, P., \&Natoli, R. (2013). Transitioning to IFRS in Australian classrooms: Impact on teaching approaches. Issues in Accounting Education, 28 (2), 263-275.

Kang, G., Liu, X. \& Hsiao, D. (2016). Are We Ready for the Changes in U.S. Accounting Standards? Some Evidence of Midwestern Universities Curriculum. Journal of Accounting - Business \& Management, 23(1), 1-14.

Kinkela, K., Harris, P. \&Malindredos, J. (2010). Introducing IFRS in Introductory Financial Accounting Courses. Business Education \& Accreditation, 2(1), 39-47.

Lakew, D. \& Musa, M. (2019). Preparedness to Teach International Financial Reporting Standards (IFRS) in Ethiopia: A Study on Selected Universities. International Journal of Commerce and Finance, 5(2), 147-157.

Lanre, N., Ranti, U., Uwalomwa, U. \&Tochukwu, A. (2014). IFRS Adoption and Its Integration into Accounting Education Curriculum in Nigerian Universities. Research Journal of Finance and Accounting, 5(22), 76-83.

NL, S. (2018). Teaching IFRS performance in accounting training in universities-development opportunities for young lecturers. Educational Research, 9(5), 145-150.

Okorie, O., Onwe, O. \&Unugo, L. (2018). International Financial Reporting Standards (IFRS) Education in Colleges of Education in Southeastern States of Nigeria. American Journal of Educational Research, 6(11), 1460-1464.

Okpala, K. (2012). Adoption of IFRS and financial statements effects: the perceived implications of FDI and Nigeria economy. Australian Journal of Business and Management Research, 2(5), 76-82.

Owolabi, F., Ilogho, S., Eluyela, D., Akomolafe, J. \& Bassey, I. (2016). International financial reporting standards education and its inclusion in the Nigerian curriculum. A paper presented at the 28th IBIMA Conference on vision 2020: Innovation Management, Development Sustainability and Competitive Economic Growth. https://ibima.org Retrieved 12th August, 2018.

Saudi Organisation for Certified Public Accountants (SOCPA) 2014a, Projects, viewed 5 October 2014.

Septriana, I. \&Fuad, A. (2020). Factors Affecting the Understanding of IFRS in Accounting Students. International Journal of Higher Education, 9(4), 302-309.

Copyright (C) 2021, Journal of Advanced Research in Economics and Administrative Sciences (JAREAS), Under a Creative Commons Attribution 4.0 International License 
Thomas, J. (2009). Convergence: Businesses and business schools prepare for IFRS. Issues in Accounting Education, 24(3), 369-376.

Yallapragada, R., Toma, A. \& Roe, C. (2011). The Impact of International Financial Reporting Standards On Accounting Curriculum In The United States. American Journal of Business Education, 4(1), 61-64.

Yilmaz, Z. \&Yazarkan, H. (2017). Comparison between Curriculums of Business Schools in Turkey and the World in Terms of IAS/IFRS Courses. New Trends and Issues Proceedings on Humanities and Social Sciences, 4,249-259. 